Chirurgia (2018) 113: 185-191

No. 2, March - April

Copyright@ Celsius

http://dx.doi.org/10.21614/chirurgia.113.2.185

\title{
Peroral Endoscopic Myotomy Versus Heller Myotomy for Achalasia: Pros and Cons
}

\author{
Cristian Tefas ${ }^{1,2}$, Rami Ababneh', Marcel Tanțău ${ }^{1,2}$ \\ 'Gastroenterology Department, "Prof. Dr. Octavian Fodor" Institute of Gastroenterology and Hepatology, Cluj-Napoca, Romania \\ 2"Iuliu Hațieganu” University of Medicine and Pharmacy, Cluj-Napoca, Romania
}

Corresponding author:

Cristian Tefas, MD

19-21 Croitorilor Street, 400162

Cluj-Napoca, Romania

E-mail: tefascristian@gmail.com

\section{Abbreviations:}

GER - gastroesophageal reflux;

LES - lower esophageal sphincter;

LHM - laparoscopic Heller myotomy;

POEM - peroral endoscopic myotomy;

\section{Rezumat}

Miotomia endoscopică perorală versus miotomia Heller în achalazie: avantaje și dezavantaje

Achalazia este o afecțiune motorie esofagiană ce cunoaşte multiple metode de tratament endoscopic şi chirurgical. $\mathrm{Cu}$ toate acestea nu există un consens referitor la terapia optimă la pacienții suferinzi de acestă afecțiune. Acest review discută două terapii cu concepte similare, dar mult diferite din punct de vedere tehnic, miotomia endoscopică perorală şi miotomia chirurgicală Heller. După o scurtă introducere în problemele fundamentale ale achalaziei, sunt prezentate considerentele tehnice, complicațiile intra şi postprocedurale şi sunt discutate avantajele şi dezavantajele celor două proceduri, pe baza articolelor relevante din literatura de specialitate. Miotomia chirurgicală Heller şi miotomia endoscopică perorală par să prezinte eficiență similară, cu rezultate asemănătoare din punctul de vedere al ratelor de reflux gastroesofagian. Cu toate acestea, pe măsura câştigării experienței în domeniul miotomiei endoscopice, această procedură pare mai avantajoasă, cu rate similare de succes fată de tehnica chirugicală consacrată, dar oferind timpi operatori mai reduşi, spitalizări mai scurte şi în cele din urmă costuri mai mici.

Cuvinte cheie: achalazie, miotomie endoscopică perorală, miotomie Heller

\section{Abstract}

Achalasia is an esophageal motor disorder that has multiple endo- 
scopic and surgical methods of treatment. However, there is no consensus on optimal therapy in patients suffering from this disorder. This review discusses two therapies with similar but technically different concepts, peroral endoscopic myotomy and Heller surgical myotomy. After a brief introduction to the basic problems of achalasia, technical considerations, intra and postprocedural complications are presented and the advantages and disadvantages of the two procedures are discussed, based on the relevant articles in the literature. Heller surgical myotomy and peroral endoscopic myotomy appear to be similar in performance with similar results in terms of gastroesophageal reflux rates. However, with experience being gained in the field of endoscopic myotomy, this procedure seems more advantageous, with similar success rates to those of the established surgical technique, but offering shorter operating times, shorter hospitalizations and, ultimately, lower costs.

Key words: achalasia, peroral endoscopic myotomy, Heller myotomy

\section{Introduction}

Achalasia is a motility disorder of the esophagus defined by three elements: the reduction or absence of the primary peristaltic waves in the distal two thirds of the esophagus, incomplete or no relaxation of the lower esophageal sphincter (LES) during swallowing and increased resting LES tone. Typical symptoms of achalasia are dysphagia, nonacid regurgitation, retrosternal pain, and weight loss. Achalasia is reported around the world with no gender differences, predominantly between the ages of 25-60 (1), affecting about one person in 100000 (2).

Therapies that have proven effective address the LES and they include laparoscopic Heller myotomy (LHM), endoscopic injection of botulinum toxin, endoscopic balloon dilatation, and peroral endoscopic myotomy (POEM). However, there is no consensus on a standard treatment in achalasia, the therapeutic option being chosen for each patient according to their preferences, age, co-morbidities, previous therapies, and the experience of the center where the patient is treated.

The aim of this review was to compare POEM to LHM for the treatment of esophageal achalasia, taking results, early and long term complications and costs into consideration.

\section{Technical Considerations Regarding LHM and POEM}

Ernst Heller first described surgical esophageal myotomy in 1913 (3). At first it consisted of transabdominal extra-mucosal myotomy on both the anterior and posterior wall of the esophagus. In 1923 this approach was modified by Zaaijer using only a myotomy on the anterior wall of the esophagus, with excellent results (4). Open abdominal and thoracic approaches can be safely performed, however they involve long recovery times. Modern Heller myotomy is done using laparoscopy and thoracoscopy, with similar outcomes and better quality of life than open techniques. The myotomy is made by dividing both esophageal muscular layers, circular and longitudinal, above the area of constriction. The incision is extended $4-6 \mathrm{~cm}$ on the esophagus and $1.5-3 \mathrm{~cm}$ onto the gastric cardia, as to ensure complete relaxation of the cardia. In order to decrease the incidence of postoperative reflux, a fundoplication is performed, meaning that the gastric fundus is plicated around the lower end of the esophagus and stitched in place. LHM was considered the standard of care for the management of achalasia for a long time, having minimal perioperative morbidity and excellent long-term functional outcomes (5).

POEM was first performed by Haruhiro Inoue in Japan in 2008 (6). Since then, the procedure has been increasingly used all 
around the world and has become a developed endoscopic technique for the treatment of achalasia. It involves the creation of a submucosal tunnel through a breach in the esophageal mucosa. This tunnel allows access to esophageal muscle fibers, which are cut through electrocautery, using an endoscopic triangle tipped knife designed specifically for this technique. Sectioning of the muscle fibers begins at $10-12 \mathrm{~cm}$ proximally to the cardia and extends $3-5 \mathrm{~cm}$ distally in the stomach, thus ensuring complete cutting of the inferior esophageal sphincter. From a technical point of view, POEM is a reversed partial LHM, one of the significant differences between the two being that in the case of POEM, the sectioning of the muscle fibers is concentrated on the inner circular layer, whereas in the case of LHM, because of the esophageal extrinsic approach, both muscular layers have to be sectioned. Some authors have tested full-thickness myotomy during POEM procedure, but with no improvement in efficacy. They however have concluded that full-thickness myotomy leads to a reduced procedural time $(7,8)$, while others have shown an increase in gastroesophageal reflux (GER) rates as opposed to circular myotomy (9).

\section{Efficacy of LHM and POEM}

LHM has fully proved its worth since it has been introduced almost a century ago, several studies showing good results even in in very long follow-ups, of 80 months or more (Table 1).

As it is a recent procedure, POEM could not be properly evaluated in the long term in multiple studies. However, from the data we have so far, POEM proves its effectiveness in the short and medium term, with studies showing satisfactory results in over $80 \%$ of patients treated with this method (Table 2). Some long term studies have been performed, in centers with a high case load of patients treated with achalasia. One study by Teitelbaum et al which followed-up patients for 5 years revealing that POEM resulted in durable longterm symptomatic relief for $83 \%$ of patients without the need for reintervention (10). A significant advantage of POEM over LHM is that in case of ineffective symptom control or relapse, a second session can be performed with good results, as $\mathrm{Li}$ et al showed on a cohort of 15 patients, the therapeutic effectiveness being $100 \%$ at one year after reintervention (11).

Table 1. Success rate of and incidence of reflux after LHM

\begin{tabular}{lccc}
\hline Authors & Follow-up (months) & Success rate & Patients with reflux \\
\hline Peng et al, 2017 (12) & 36 & $80 \%$ & $6,7 \%$ \\
\hline Leeds et al, 2017 (13) & 6 & $66 \%$ & No information \\
\hline Moonen et al, 2016 (14) & 60 & $84 \%$ & No information \\
\hline Salvador et al, 2016 (15) & 49 & $88,9 \%$ & $11,6 \%$ \\
\hline Persson et al, 2015 (16) & 80,4 & $92 \%$ & No information \\
\hline Hamdy et al, 2015 (17) & 48 & $88 \%$ & $28 \%$ \\
\hline Krishnamohan, 2014 (18) & 77,5 & $49,8 \%$ & $70,5 \%$ \\
\hline
\end{tabular}

Table 2. Success rate of and incidence of reflux after POEM

\begin{tabular}{lccc}
\hline Authors & Follow-up (months) & Success rate & Patients with reflux \\
\hline Peng et al, 2017 (12) & 36 & $83,3 \%$ & $8,3 \%$ \\
\hline Leeds et al, 2017 (13) & 6 & $82 \%$ & No information \\
\hline Teitelbaum et al, 2017 (10) & 60 & $84 \%$ & No information \\
\hline Hungness et al, 2016 (19) & 28 & $92 \%$ & $27 \%$ \\
\hline Werner et al, 2016 (20) & 29 & $77,5 \%$ & $37 \%$ \\
\hline Inoue et al, 2015 (21) & 36 & $88,5 \%$ & $21,3 \%$ \\
\hline Chen et al, 2015 (22) & 24 & $100 \%$ & $6,7 \%$ \\
\hline
\end{tabular}


One of the biggest questions regarding POEM is how well it fares when compared to LHM, in short, medium and long-term followup. Talukdar et al have performed a systematic review and meta-analysis on 29 studies including 1045 patients, and concluded that POEM has similar outcomes as LHM, with no differences between POEM and LHM in reduction in Eckhart's score. However, the authors take note of a significant heterogeneity among the study, which could have influenced the results (23). A similar large meta-analysis by Marano et al compared POEM and LHM, revealing that POEM has a slightly better maintenance of a lower Eckardt score than LHM, but the difference didn't reach statistical significance. The authors also showed that there were no significant differences between the two techniques regarding duration of intervention, postoperative pain score and analgesic requirement (24). A recent systematic review and metaanalysis of 53 articles including both LHM and POEM performed on a total of 1958 patients revealed comparable results between the two techniques. As such, predicted probabilities for improvement in dysphagia at 12 months were 93.5\% for POEM and 91.0\% for LHM ( $<<0.01)$, while at 24 months they were $92.7 \%$ for POEM and $90.0 \%$ for LHM $(\mathrm{P}<0.01)$. However, across all included studies, dysphagia improved in $93.2 \%$ of patients who underwent POEM and $87.7 \%$ of patients who were treated with LHM, showing that at least in short-term, POEM is superior than LHM (25). Concerning medium to long term efficacy, a 3 year follow-up study by Peng et al indicated that POEM is an effective treatment that is comparable with LHM (12).

Ujiki et al compared POEM to LHM concluding that procedural time, the length of myotomy and complication rates were similar. After treatment, pain evaluated using a visual analogue scale was significantly worse in the LHM group as opposed to the POEM one (LHM $5.7 \pm 0.4$ vs POEM $3.9 \pm 0.6$, $\mathrm{p}=0.02$ ). As such, pain relief medication use was lower after endoscopic therapy (POEM $26.0 \pm 13.7 \mathrm{mg}$ vs LHM $90.0 \pm 48.5 \mathrm{mg}$ morphine, $p=0.02$ ) (26). However, Hungness et al reported different results, as they noted that pain scores were similar upon arrival in the post-anesthesia care unit and on the first postoperative day, but were higher 2 hours after the procedure for POEM patients (3.5 vs $2, p=0.03)(27)$.

Although some earlier studies report a similar procedural time between POEM and LHM, others report a shorter time in favor of POEM. This phenomenon is plausible in terms of the initial lack of operator experience. As experience accumulates, the difference in time between the two procedures should become significant.

\section{Complications of LHM and POEM}

The rate of complications related to LHM is low, with most of the studies showing a rate between $0-9 \%$ (28). Of these, perhaps the most feared complication is esophageal perforation, as reintervention is needed in order to suture the breach.

The main adverse effects that may be encountered in POEM are bleeding, mucosal perforations, infections or events related to endoscopic insufflation, such as pneumoperitoneum or pneumothorax. In order to avoid these events, POEM must be performed by experienced endoscopists, with extensive training in esophageal disorders. Most studies have shown that approximately 20 cases are sufficient to accomplish training for POEM as an experienced endoscopist, after which the length of the procedure and accidental mucosal damage plateaus (29-31).

Mucosal perforation, seen in up to $10 \%$ of cases (32), can be a real problem especially if it is not recognized on time, as the mucosal layer maintains the integrity of the digestive tract after performing POEM. When mucosal lesions are identified, endoscopic management is fairly simple, using hemostatic clips to close them. If the perforations are larger, endoscopic suturing or the placement of fully covered metal stents can be used.

Events related to insufflation are probably the most common, being observed during POEM as well as post procedurally in about $20 \%$ of cases (23). However, they are not life 
threatening as long as the necessary precautions are taken. In this respect, it is imperative to use CO2 insufflation during endoscopy because of its much faster absorption rate as opposed to air. At the same time, low or very low flow rates are recommended, so that gas accumulation is minimal. If pneumoperitoneum occurs during the procedure, it can be resolved quickly by transombilical drainage with a Veress needle.

\section{Gastroesophageal Reflux in LHM and POEM}

As during the Heller myotomy, the entire esophageal sphincter that secures the antireflux barrier is cut, it is mandatory to complete the intervention with an anti-reflux procedure, such as a Toupet or Dor fundoplication, in order to prevent post-operative gastro-esophageal reflux. This has been thoroughly validated across time. A prospective randomized trial performed by Richards et al evidenced a pathological GER rate of $47.6 \%$ when no antireflux procedure was added to LHM, compared to a $9.1 \%$ rate in the group with Heller myotomy followed by anterior fundoplication. The authors also showed that there was no significant statistical differences between the two groups regarding postoperative dysphagia (33). Similar GER rates of up to $10 \%$ have been shown by other authors when adding an antireflux procedure to LHM (34-37).

As opposed to LHM, during POEM there is no dissection of the phrenoesophageal membrane, which may maintain anatomical reflux barriers. What's more, during POEM only the circular muscular layer is sectioned. Surprisingly however, results from multiple studies that have compared POEM to LHM show similar GER rates between the two techniques (12,38-40), with an incidence ranging between $0 \%$ and $37 \%$ (24).

However, the method by which reflux is evaluated is very important. Thus, if symptomatic and endoscopic scores provide similar results between the two techniques, goldstandard evaluation by $\mathrm{pH}$ monitoring shows the presence of much higher reflux rates in patients treated with POEM. As such,
Schlottmann et al showed a pathological reflux rate of $11,1 \%$ in LHM patients and in $47,5 \%$ of POEM patients (25). The reason for this is still discussed, but the lack of an antireflux procedure in POEM might be the main reason. Even if in all cases reflux symptoms can be completely controlled by proton pump inhibitors therapy (21), emerging side effects of long term therapy with these drugs have to be taken into account.

\section{Cost of LHM vs POEM}

Intuitively we could say that POEM should be cheaper than LHM. It is a less invasive procedure, the approach being endoscopic as opposed to surgical, so the duration of the intervention is reduced and requires less personnel. However, the few studies that have analyzed the problem have come to a different conclusion, namely that there is no significant cost difference between the two procedures (41).

Khashab et al have compared POEM to robotic Heller myotomy (RHM) and found POEM to be cheaper and shorter in duration, but with a similar efficacy and safety. However, Shaligram et al have compared LHM to RHM beforehand and found higher costs with the latter procedure (42). As such, comparing POEM to LHM might yield more similar costs. Khashab et al noted that there was a similar length of stay between the patients who underwent POEM and those who underwent RHM. The difference in costs between the two groups might be attributable to the fact that those treated with RHM needed an increased post procedural support (41).

Miller et al concluded that the cost effectiveness of POEM and LHM is equivalent (43). Greenleaf et al reported similar costs in POEM and LHM, attributable to a greater mean cost of radiological assessments after POEM and to a longer mean stay in the post-anesthesia care unit, which typically lasted 24 hours, as opposed to patients who underwent LHM and were transferred on general surgical wards much sooner. However, the authors note that with further experience in POEM the costs will surely drop, as procedural times, number of 
endoclips used, radiological assessments and length of stay in post-anesthesia care units will be greatly reduced (44). There might come a time when POEM will be performed as a oneday endoscopic surgery procedure.

\section{Conclusion}

POEM seems to be here to stay, as multiple studies showed that its effectiveness is similar to that of LHM, while others showed it may be better. POEM is less invasive and may result in shorter hospitalization, and quicker return to normal activity while still providing durable long-term symptomatic relief, with a reduced cost in hospitalization. We believe it is time to consider POEM as gold standard for the treatment of achalasia.

\section{Authors' Contributions}

$\mathrm{CT}$ and RA have drafted the article. MT has revised the article.

\section{Conflict of Interests}

The authors declare no conflict of interests for this article.

\section{Funding}

The authors declare that no specific funding has been received for this study.

\section{References}

1. Francis DL, Katzka DA. Achalasia: Update on the disease and its treatment. Gastroenterology. 2010. p. 369-74.

2. Lake JM, Wong RKH. Review article: the management of achalasia - a comparison of different treatment modalities. Aliment Pharmacol Ther. 2006;24(6):909-18.

3. Heller E. Extramukose cardioplastik bein chronischen Cardiospasmus mit Dilatation des Oesophagus. Mitteilungen aus Den Grenzgebieten Der Medizin Und Chir. 1913;27.

4. Zaaijer J. Cardiospasm in the Aged. Ann Surg. 1923;77(5):615-7.

5. Stefanidis D, Richardson W, Farrell TM, Kohn GP, Augenstein V, Fanelli RD. SAGES guidelines for the surgical treatment of esophageal achalasia. Surgical Endoscopy and Other Interventional Techniques. Springer-Verlag; 2012. p. 296-311.

6. Inoue H, Minami H, Kobayashi Y, Sato Y, Kaga M, Suzuki M, et al. Peroral endoscopic myotomy (POEM) for esophageal achalasia. Endoscopy. 2010;42(4):265-71.

7. Li C, Gong A, Zhang J, Duan Z, Ge L, Xia N, et al. Clinical Outcomes and Safety of Partial Full-Thickness Myotomy versus Circular Muscle Myotomy in Peroral Endoscopic Myotomy for Achalasia Patients.
Gastroenterol Res Pract. 2017;2017:1-7.

8. Li QL, Chen WF, Zhou PH, Yao LQ, Xu MD, Hu JW, et al. Peroral endoscopic myotomy for the treatment of achalasia: A Clinical comparative study of endoscopic full-thickness and circular muscle myotomy. J Am Coll Surg. 2013;217(3):442-51.

9. Wang XH, Tan YY, Zhu HY, Li CJ, Liu DL. Full-thickness myotomy is associated with higher rate of postoperative gastroesophageal reflux disease. World J Gastroenterol. 2016;22(42):9419-26.

10. Teitelbaum EN, Dunst CM, Reavis KM, Sharata AM, Ward MA, DeMeester SR, et al. Clinical outcomes five years after POEM for treatment of primary esophageal motility disorders. Surgical Endoscopy and Other Interventional Techniques. 2017;1-7.

11. Li QL, Yao LQ, Xu XY, Zhu JY, Xu MD, Zhang YQ, et al. Repeat peroral endoscopic myotomy: A salvage option for persistent/ recurrent symptoms. Endoscopy. 2016;48(2):134-40.

12. Peng L, Tian S, Du C, Yuan Z, Guo M, Lu L. Outcome of Peroral Endoscopic Myotomy (POEM) for treating achalasia compared with Laparoscopic Heller Myotomy (LHM). Surg Laparosc Endosc Percutaneous Tech. 2017:27(1):60-4.

13. Leeds SG, Burdick JS, Ogola GO, Ontiveros E. Comparison of outcomes of laparoscopic Heller myotomy versus per-oral endoscopic myotomy for management of achalasia. Proc (Bayl Univ Med Cent). 2017;30(4):419-23.

14. Moonen A, Annese V, Belmans A, Bredenoord AJ, Varannes SB Des, Costantini M, et al. Long-term results of the European Achalasia trial: A multicentre randomised Controlled trial comparing pneumatic dilation versus laparoscopic Heller myotomy. Gut. 2016;65(5):732-9.

15. Salvador R, Pesenti E, Gobbi L, Capovilla G, Spadotto L, Voltarel G, et al. Postoperative Gastroesophageal Reflux After Laparoscopic HellerDor for Achalasia: True Incidence with an Objective Evaluation. J Gastrointest Surg. 2017;21(1):17-22.

16. Persson J, Johnsson E, Kostic S, Lundell L, Smedh U. Treatment of achalasia with laparoscopic myotomy or pneumatic dilatation: Longterm results of a prospective, randomized study. World J Surg. 2015; 39(3):713-20.

17. Hamdy E, El Nakeeb A, El Hanfy E, El Hemaly M, Salah T, Hamed H, et al. Comparative study between laparoscopic Heller myotomy versus pneumatic dilatation for treatment of early achalasia:a prospective randomized study. J Laparoendosc Adv Surg Tech. 2015;25(6):460-4.

18. Krishnamohan P, Allen MS, Shen KR, Wigle DA, Nichols FC, Cassivi $\mathrm{SD}$, et al. Long-term outcome after laparoscopic myotomy for achalasia. J Thorac Cardiovasc Surg. 2014;147(2):730-6-7.

19. Hungness ES, Sternbach JM, Teitelbaum EN, Kahrilas PJ, Pandolfino JE, Soper NJ. Per-oral endoscopic myotomy (POEM) after the learning curve: Durable long-term results with a low complication rate. Ann Surg. 2016;264(3):508-15.

20. Werner YB, Costamagna G, Swanström LL, Von Renteln D, Familiari P, Sharata AM, et al. Clinical response to peroral endoscopic myotomy in patients with idiopathic achalasia at a minimum follow-up of 2 years. Gut. 2016;65(6):899-906.

21. Inoue $\mathrm{H}$, Sato $\mathrm{H}$, Ikeda $\mathrm{H}$, Onimaru $\mathrm{M}$, Sato $\mathrm{C}$, Minami $\mathrm{H}$, et al. Per-Oral Endoscopic Myotomy: A Series of 500 Patients. J Am Coll Surg. 2015;221(2):256-64.

22. Chen X, Li QP, Ji GZ, Ge XX, Zhang XH, Zhao XY, et al. Two-year follow-up for 45 patients with achalasia who underwent peroral endoscopic myotomy. Eur J Cardio-thoracic Surg. 2015;47(5):890-6.

23. Talukdar R, Inoue H, Reddy DN. Efficacy of peroral endoscopic myotomy (POEM) in the treatment of achalasia: a systematic review and meta-analysis. Surg Endosc Other Interv Tech. 2015;29(11): 3030-46.

24. Marano L, Pallabazzer G, Solito B, Santi S, Pigazzi A, De R, et al. Surgery or peroral esophageal myotomy for Achalasia: A systematic review and meta-analysis. Med (United States). 2016; 95(10):e3001.

25. Schlottmann F, Luckett DJ, Fine J, Shaheen NJ, Patti MG. Laparoscopic Heller Myotomy Versus Peroral Endoscopic Myotomy (POEM) for Achalasia: A Systematic Review and Meta-analysis. Ann Surg. 2018; 267(3):451-460. doi: 10.1097/SLA.0000000000002311.

26. Ujiki MB, Yetasook AK, Zapf M, Linn JG, Carbray JM, Denham W. Peroral endoscopic myotomy: A short-term comparison with the stan- 
dard laparoscopic approach. Surg (United States). 2013;154(4): 893-900.

27. Hungness ES, Teitelbaum EN, Santos BF, Arafat FO, Pandolfino JE, Kahrilas PJ, et al. Comparison of Perioperative Outcomes Between Peroral Esophageal Myotomy (POEM) and Laparoscopic Heller Myotomy. J Gastrointest Surg. 2013;17(2):228-35.

28. Ross SW, Oommen B, Wormer BA, Walters AL, Matthews BD, Heniford BT, et al. National outcomes of laparoscopic Heller myotomy: operative complications and risk factors for adverse events. Surg Endosc Other Interv Tech. 2015;29(11):3097-105.

29. Tanțău M, Buzaș C, Tefas C, Tanțău A. Learning curve for the POEM procedure. Journal of Gastrointestinal and Liver Diseases. 2015. p. 537-8.

30. Kurian AA, Dunst CM, Sharata A, Bhayani NH, Reavis KM, Swanström LL. Peroral endoscopic esophageal myotomy: Defining the learning curve. Gastrointest Endosc. 2013;77(5):719-25.

31. Tantau M, Crisan D. Peroral endoscopic myotomy: Time to change our opinion regarding the treatment of achalasia? World J Gastrointest Endosc. Baishideng Publishing Group Inc; 2015;7(3): 237-46.

32. Familiari P, Gigante G, Marchese M, Boskoski I, Tringali A, Perri V, et al. Peroral endoscopic myotomy for esophageal Achalasia: Outcomes of the first 100 patients with short-term follow-up. Ann Surg. 2016;263(1):82-7.

33. Richards WO, Torquati A, Holzman MD, Khaitan L, Byrne D, Lutfi R, et al. Heller myotomy versus heller myotomy with dor fundoplication for achalasia: A prospective randomized double-blind clinical trial. In: Annals of Surgery. Lippincott, Williams, and Wilkins; 2004. p.405-15.

34. Anselmino M, Zaninotto G, Costantini M, Rossi M, Boccu' C, Molena D, et al. One-year follow-up after laparoscopic Heller-Dor operation for esophageal achalasia. Surg Endosc. 1997;11(1):3-7.

35. El Hak NG, Hamdy E, Abdalla T, Kandel T, El Raof AA, El Hemaly M, et al. Laparoscopic heller myotomy for achalasia: analysis of successes and failures. Hepatogastroenterology. 2012:59(117):1450-4.

36. Ancona E, Peracchia A, Zaninotto G, Rossi M, Bonavina L, Segalin A. Heller laparoscopic cardiomyotomy with antireflux anterior fundoplication (Dor) in the treatment of esophageal achalasia. Surg Endosc. 1993;7(5):459-61.

37. Bonavina L, Nosadini A, Bardini R, Baessato M, Peracchia A. Primary Treatment of Esophageal Achalasia: Long-term Results of Myotomy and Dor Fundoplication. Arch Surg. 1992;127(2):222-7.

38. Schneider AM, Louie BE, Warren HF, Farivar AS, Schembre DB, Aye RW. A Matched Comparison of Per Oral Endoscopic Myotomy to Laparoscopic Heller Myotomy in the Treatment of Achalasia. J Gastrointest Surg. 2016;20(11):1789-96.

39. Swanstrom LL, Kurian A, Dunst CM, Sharata A, Bhayani N, Rieder E. Long-term outcomes of an endoscopic myotomy for achalasia: The POEM procedure. In: Annals of Surger. 2012. p. 659-67.

40. Teitelbaum EN, Soper NJ, Santos BF, Arafat FO, Pandolfino JE, Kahrilas $\mathrm{PJ}$, et al. Symptomatic and physiologic outcomes one year after peroral esophageal myotomy (POEM) for treatment of achalasia. Surg Endosc. 2014;28(12):3359-65.

41. Khashab MA, Kumbhari V, Tieu AH, El Zein MH, Ismail A, Ngamruengphong $\mathrm{S}$, et al. Peroral endoscopic myotomy achieves similar clinical response but incurs lesser charges compared to robotic heller myotomy. Saudi J Gastroenterol. Wolters Kluwer -- Medknow Publications; 2017:23(2):91-6.

42. Shaligram A, Unnirevi J, Simorov A, Kothari VM, Oleynikov D. How does the robot affect outcomes? A retrospective review of open, laparoscopic, and robotic Heller myotomy for achalasia. Surgical Endoscopy and Other Interventional Techniques. 2012. p. 1047-50.

43. Miller HJ, Neupane R, Fayezizadeh M, Majumder A, Marks JM. POEM is a cost-effective procedure: cost-utility analysis of endoscopic and surgical treatment options in the management of achalasia. Surg Endosc Other Interv Tech. 2017;31(4):1636-42.

44. Greenleaf EK, Winder JS, Hollenbeak CS, Haluck RS, Mathew A, Pauli EM. Cost-effectiveness of per oral endoscopic myotomy relative to laparoscopic Heller myotomy for the treatment of achalasia. Surg Endosc. 2018;32(1):39-45. 